\title{
EVALUATION OF THE CONTACT ANGLE OF HYDROPHOBISED LIGHTWEIGHT-AGGREGATE CONCRETE WITH SEWAGE SLUDGE
}

\author{
OCENA KĄTA ZWILŻANIA HYDROFOBIZOWANEGO KERAMZYTOBETONU \\ Z OSADEM ŚCIEKOWYM
}

\begin{abstract}
The aim of the research presented in the paper was to evaluate the feasibility of using hydrophobic preparations based on organosilicon compounds for protection treatment of lightweight aggregates modified with municipal sewage sludge. Issues related to the wettability of the surface layer of hydrophobised lightweight-aggregate concrete supplemented with sewage sludge are discussed in the paper. The experimental part of the study is focused on the physical and mechanical characteristics of lightweight-aggregate concrete and the effect of two hydrophobic preparations on the contact angle of the material. The contact angle for lightweight concrete $\left(\theta_{w}\right)$ was determined as a function of time using one measurement liquid. The hydrophobic coatings in the structure of lightweight concrete modified with sewage sludge were shown using electron microscopy. The investigations demonstrated the effectiveness of hydrophobisation of porous lightweight concretes. On the hydrophobic surfaces, the contact angles decreased with time and depended on the preparations used. The results of the research confirm the possibility to produce lightweight aggregate-concretes modified with sewage sludge with appropriate surface protection against external moisture.
\end{abstract}

Keywords: lightweight aggregate-concrete, sewage sludge, hydrophobisation, contact angle, microstructure

\section{Introduction}

Given the existing legal norms and standardisation of the EU regulations of environmental protection, management of sewage sludge has become an important economic, ecological, and technological issue [1]. This is a growing problem due to the fact that introduction of new and more efficient methods for biological wastewater treatment by removal of biogens and organic carbon compounds with the use of activated sludge results

\footnotetext{
${ }^{1}$ Department of Building Construction, Faculty of Civil Engineering and Architecture, Lublin University of Technology, ul. Nadbystrzycka 40, 20-618 Lublin, Poland, email: d.barnat-hunek@ pollub.pl

${ }^{2}$ Department of Civil Engineering, Faculty of Civil Engineering and Architecture, Lublin University of Technology, ul. Nadbystrzycka 40, 20-618 Lublin, Poland, email: p.smarzewski@ pollub.pl

${ }^{3}$ Department of Water Supply and Wastewater Disposal, Faculty of Environmental Engineering, Lublin University of Technology, ul. Nadbystrzycka 40a, 20-618 Lublin, Poland, email: g.lagod@ pollub.pl

* Corresponding author: g.lagod@ pollub.pl
} 
in increased production of sludge in the existing wastewater treatment plants. New wastewater treatment plants that are being established in the individual provinces and across the country generate additional quantities of sewage sludge. One of the examples of the numerous problems concerning the increased production of sewage sludge is the municipal wastewater treatment plant in Lublin. The "Hajdow" plant collecting sanitary and industrial wastewater from the cities of Lublin, Swidnik, and surrounding areas is a mechanical-biological wastewater treatment plant employing the activated sludge technology. Sludge formed during the wastewater treatment process (primary and excess sludge) is dewatered, subjected to mesophilic fermentation, and compacted. The rate of wastewater treatment is on average $65000 \mathrm{~m}^{3} /$ day and the amount of fermented sludge reaches approximately $600 \mathrm{~m}^{3} /$ day [2]. This shows that the amount of produced sludge is considerable and highlights the necessity to search for a new possibilities of disposal and management thereof, besides the existing solutions, ie thermal utilisation [3,4] as well as natural management and agricultural use [5,6]. It should be mentioned here that sewage sludge from large municipal wastewater treatment plants containing eg heavy metals will not necessarily be suitable for the use in land application and agriculture [7]. In such a case, one of the ways of utilisation of this type of sewage sludge involves application thereof for production of building materials eg lightweight aggregate [8-10], in which it serves a function of a bulking agent and contributes to the highly porous texture of sintered ceramics. Lightweight aggregate can be used to produce energy-efficient [11-13], ecological lightweight-aggregate concrete blocks for building construction. Sludge has also been successfully applied in manufacturing of ceramic bricks, as reported in [14].

Lightweight-aggregate concrete modified with sewage sludge and used for production of energy-efficient blocks is characterised by higher porosity and water absorption capacity than its commercial counterpart, which is related to the porous structure of lightweight aggregate containing sewage sludge [10]. This poses a major problem while designing the composition of lightweight-aggregate concrete mixes. In the ready product, it causes capillary water transport [15], which has a significant effect on the heat flow process by inducing a several-fold increase in thermal conductivity of materials [16-18].

Moisture damage is a major factor in deterioration of building materials [19, 20]. One of the methods used to protect the lightweight aggregate-concrete surface is hydrophobisation $[21,22]$. It causes a decrease in capillary water absorption, thus allowing free vapour permeability. Preparations based on organosilicon compounds, siloxanes, or methyl silicone resins [23, 24] are used for hydrophobisation of concrete most frequently. Also, it ought to be mentioned here that polymer-cement concretes (PCC) obtained by addition of a polymer, oligomer, or monomer of the above mentioned substances to the concrete mix have gained increasing popularity. The resulting concretes are characterised by better workability of the mix and higher tensile strength than that of ordinary concrete [25]. Polymer impregnated concretes (PIC) produced by impregnation of hardened concrete with a mentioned monomer or prepolymer are popular in the existing facilities.

There are literature reports on the application of silanes for modification of the material surface [26, 27] or in concrete [28] or mortar [29-31] mixes. These compounds ensure hydrophobicity of concrete surfaces against water and repellence of corrosive compounds, $e g$ water-soluble salts [32]. The wettability of building materials towards liquids is of particular importance for hydrophobisation and impregnation thereof and for the effectiveness of anti-graffiti agents devised for cleaning surfaces. 
The contact angle of materials is an indicator of their wettability properties [33]. High wettability occurs at a low contact angle $<90^{\circ}$, and hydrophobicity at a high contact angle $>90^{\circ}$. The contact angle can be used to determine surface tension [34] and define surface free energy (SFE) [35] and adhesion operation [36]. Specific adhesion can be evaluated by studying the interfacial and surface forces acting at the interface, which specifies the conditions for good wettability and spreading. Good wettability contributes to a better fulfilling of the concrete surface profile by the repair material [37].

The contact angle is influenced by a variety of factors, eg surface roughness and contamination, surface homogeneity, modulus of elasticity of the analysed material, type of the measurement liquid, size of measurement liquid droplets, moisture, or ambient temperature [38]. There are many methods of determination of the contact angle. The most common of these include the air bubble method, the geometrical method, the method of the capillary rise of the liquid in the sample, and the method of direct measurement [33]. A popular method for determination of the contact angle is the direct measurement with the use of a contact angle analyser or goniometer [39, 40].

Depending on the characteristics of impregnating preparations, it is possible to decrease or increase the contact angle as well as the surface tension of the material, thereby providing them with hydrophobicity, which is associated with $e g$ chemical corrosion resistance and frost resistance.

Analysis of the structure of the surface layer of impregnated lightweight-aggregate concretes modified with sewage sludge in terms of their wettability will allow evaluation of $e g$ the behaviour of the material in the presence of water and corrosive compounds. When considerable resistance of the surface layer of lightweight concretes to the action of a corrosive environment is required, it is advisable that formulations ensuring the greatest angle should be used.

\section{Materials and methods}

\section{Concrete mixtures}

The basic components of the lightweight-aggregate concrete mixture were cement CEM I $32.5 \mathrm{R}$, lightweight aggregates with sewage sludge $(8-16 \mathrm{~mm})$, sand $(0-2 \mathrm{~mm})$, and water from the municipal water supply system. Concrete samples were prepared on the basis of a formula established experimentally based on standards EN 206-1:2003 [41] and PN-B-06265:2004 [42].

The composition of the lightweight concrete per $1 \mathrm{~m}^{3}$ was as follows: cement $288.7 \mathrm{~kg}$, sand $-483.7 \mathrm{~kg}$, aggregate with sewage sludge $-557 \mathrm{~kg}$, water $-230 \mathrm{~kg}$.

After mixing the components thoroughly and after placing the concrete in molds, it was compacted on a vibrating table. Samples with the following dimensions: $150 \times 150 \times 150 \mathrm{~mm}$ were formed directly after concrete compounds had been mixed. They were condensed in two layers by vibrations until the cement grout appeared at the surface of the mortar. All the samples were protected against moisture loses and had been stored for 24 hours in the temperature about $23^{\circ} \mathrm{C}$ until stripping. Then they were placed in a water container for a period of 14 days. Later, the samples were kept in constant laboratory conditions to fulfil the period of 28 days of maturing to be ready for further examinations.

Figure 1 presents a fracture of lightweight aggregate grains with sewage sludge and sample of lightweight-aggregate concrete after assessment frost-resistance test. 
a)

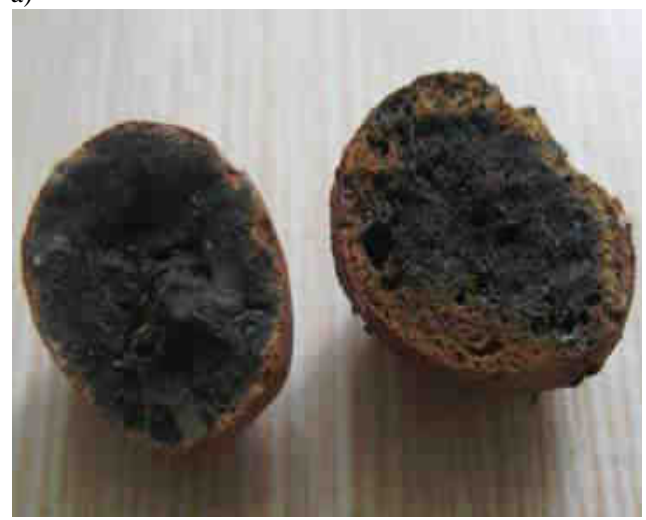

b)

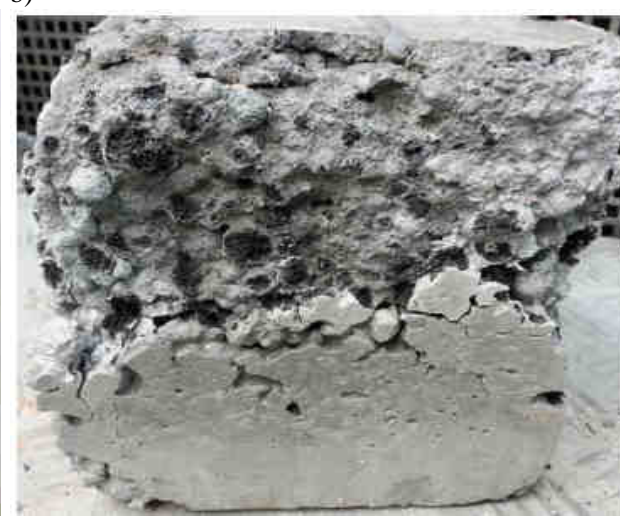

Fig. 1. Samples used for examinations: a) lightweight aggregate with sewage sludge burnt at a temperature of $1150^{\circ} \mathrm{C}$ - fracture, b) sample of lightweight-aggregate concrete with sewage sludge after 30 freezing cycles

The exact characteristics of the sewage sludge and the lightweight aggregate were presented by the authors of this article in publication [10]. The tested material used for production of lightweight aggregate was sewage sludge taken from the municipal wastewater treatment plant "Hajdow" in Lublin and clay. The sewage sludge from the wastewater treatment plant used for production of the lightweight aggregate was characterised by $80.43 \%$ moisture, $750 \mathrm{mg} \mathrm{CaCO} / \mathrm{dm}^{3}$ alkalinity, $\mathrm{pH} 7.68$, VFA $92 \mathrm{mg} / \mathrm{dm}^{3}$, COD - $13642.3 \mathrm{mg} \mathrm{O} / \mathrm{dm}^{3}, 19.57 \%$ dry weight, $60.65 \%$ loss on ignition, $39.35 \%$ residue on ignition, and $0.795 \mathrm{~g} / \mathrm{cm}^{3}$ density. Analysis of the content of heavy metals in the sewage sludge indicated presence of $1.539 \mathrm{ppm}$ of cadmium, $14 \mathrm{ppm}$ of chromium, $8.1 \mathrm{ppm}$ of nickel, and $4.9 \mathrm{ppm}$ of lead ions [10].

Sewage sludge was dried to constant mass at a temperature of $105^{\circ} \mathrm{C}$; next, it was ground in a mortar grinder to the fraction below $1.0 \mathrm{~mm}$. After grinding, the dried sludge was supplemented with clay ( $90 \%$ by weight) in the amount of $10 \%$ by weight. The process leading to homogeneity of the substance involved mixing the components with a corresponding portion of water until achievement of plastic consistency. Next, the formed balls of the 8 to $16 \mathrm{~mm}$ coarse fraction were dried to the air-dry state and placed in a laboratory oven at $110^{\circ} \mathrm{C}$ for $2 \mathrm{~h}$. The dried samples were placed in a chamber furnace and burnt at $1150^{\circ} \mathrm{C}$ for 30 minutes.

The physical and mechanical properties of the lightweight aggregate are presented in Table 1.

Table 1

Physical and mechanical properties of the lightweight aggregate burnt at the temperature of $1150^{\circ} \mathrm{C}$

\begin{tabular}{|c|c|c|c|}
\hline Parameter & Value & Parameter & Value \\
\hline Dry particle density $\rho_{d}\left[\mathrm{~kg} / \mathrm{m}^{3}\right]$ & 2620 & Porosity [\%] & 70 \\
\hline Apparent particle density $\rho_{a}\left[\mathrm{~kg} / \mathrm{m}^{3}\right]$ & 880 & Frost resistance [\%] & 2.0 \\
\hline Bulk density $\rho_{b}\left[\mathrm{~kg} / \mathrm{m}^{3}\right]$ & 510 & Resistance to crushing $X_{r}[\%]$ & 32.1 \\
\hline Absorption capacity $[\%]$ & 17.8 & & \\
\hline
\end{tabular}




\section{Properties of lightweight-concrete}

The physical and mechanical properties of the lightweight-aggregate concrete were determined on the basis of standards EN 1936:2010 [43], PN-EN 1389:2005 [44], PN-EN 12390-7:2011P [45] and PN-B-06250:1988 [46].

\section{Hydrophobic materials used}

Two commonly used hydrophobic formulations differing in the type of the solvent, viscosity, and density were selected for the laboratory analyses:

A1 - water-based solution of methylosilicone resin in the potassium hydroxide,

A2 - organic solvent-based methylosilicone resin.

The basic characteristics of the formulations used in the analyses are presented in Table 2.

Table 2

Basic characteristics of hydrophobising preparations

\begin{tabular}{|c|c|c|c|c|}
\hline $\begin{array}{c}\text { Type of } \\
\text { formulation }\end{array}$ & $\begin{array}{c}\text { Viscosity } \\
\boldsymbol{\eta}\left[\mathbf{P a} \cdot \mathbf{s}^{\cdot} \mathbf{1 0}^{-\mathbf{3}}\right]\end{array}$ & $\begin{array}{c}\text { Surface tension } \\
\boldsymbol{\sigma}\left[\mathbf{N} / \mathbf{m}^{\left.-10^{-3}\right]}\right.\end{array}$ & $\begin{array}{c}\text { The quotient of the } \\
\text { surface tension and } \\
\text { viscosity } \boldsymbol{\sigma} / \boldsymbol{\eta}\end{array}$ & $\begin{array}{c}\text { Density at 20 } \\
{\left[\mathbf{g} / \mathbf{c m}^{\mathbf{3}}\right]}\end{array}$ \\
\hline $\mathrm{A} 1$ & 1.099 & 67.92 & 61.73 & 1.26 \\
\hline $\mathrm{A} 2$ & 2.846 & 24.30 & 8.54 & 0.80 \\
\hline
\end{tabular}

The lowest viscosity value $\eta$ was found for the formulation characterised by the lowest concentration of the active substance, ie the water solution of A1. The organic solvent-based methylosilicone resin A2 was characterised by viscosity that was by nearly $250 \%$ higher than that of A1. The greatest quotient of the surface tension and viscosity was exhibited by the water-soluble coating A1.

The investigations did not involve analysis of the concentration of the formulation or the number of the coating layers. Two layers of the formulations were applied with a brush using the "wet-on-wet" technique.

\section{Determination of the contact angle}

The measurement of the contact angle with a droplet of the measurement liquid was performed on a bench consisting of a goniometer integrated with a camera taking images of the drop applied to the surface of the samples. Distilled water was used as a measurement liquid for analysis of the contact angle. $2 \mathrm{~mm}^{3}$ droplets of the liquid were micropipetted on the surface [33, 47].

a)

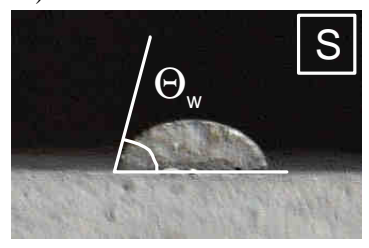

b)

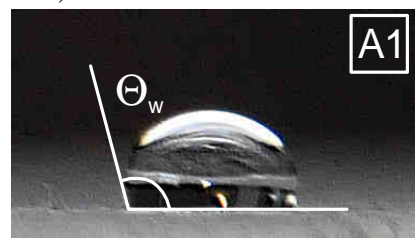

c)

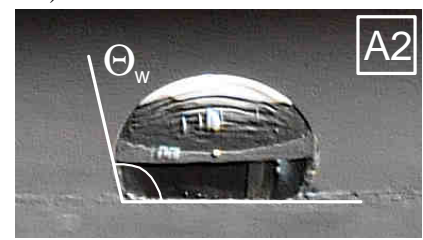

Fig. 2. Standard and hydrophobised surfaces of lightweight-concrete during examining the contact angle of a water drop: a) sample standard - S, b) water-soluble preparation - A1, c) organic solvent-based methylosilicone resin - A2 
Due to the heterogeneity of the material, 5 drops were applied to each sample. The measurements were performed at three time points: at the time of application of the drop and after 5 and 40 minutes. Figure 2 shows measurements of the contact angle in standard and hydrophobised samples at the beginning of the analysis $\left(t_{1}=0 \mathrm{~s}\right)$.

\section{Scanning electron microscopy of the hydrophobised lightweight-concrete}

The analysis of the morphology and microtopography of the hydrophobised lightweight-concrete was carried out using a scanning electron microscope FEI Quanta 250 FEG equipped with a system of chemical composition analysis based on energy dispersion spectroscopy (EDS). Samples were prepared in the form of thin-layer plates, on which $\mathrm{X}$-ray microanalysis was performed in the field mode and the composition of elements was determined for the concrete. The sample preparation methodology excludes formation of microdefects associated with cracking of the concrete surface and hydrophobic coatings. In order to avoid the formation of other surface defects, low vacuum and beam energy were used during the SEM analysis.

\section{Results}

\section{Properties of lightweight concrete}

The physical and mechanical properties of the analysed lightweight concrete modified with sewage sludge are presented in Table 3.

Table 3

Parameters of lightweight aggregate-concrete

\begin{tabular}{|c|c|c|c|}
\hline Parameter & Value & Parameter & Value \\
\hline Density $\rho_{d}\left[\mathrm{~kg} / \mathrm{m}^{3}\right]$ & 2650 & $\begin{array}{c}\text { Heat conductivity coefficient } \lambda \\
{[\mathrm{W} / \mathrm{m} \cdot \mathrm{K}]}\end{array}$ & 0.52 \\
\hline Apparent density $\rho_{a}\left[\mathrm{~kg} / \mathrm{m}^{3}\right]$ & 1112 & Compressive strength [MPa] & 10.16 \\
\hline Absorption capacity [\%] & 12.21 & Modulus of elasticity [GPa] & 21.2 \\
\hline Tightness [\%] & 41.67 & $\begin{array}{c}\text { Frost resistance [\%] weight loss after } \\
25 \text { cycles }\end{array}$ & 8.2 \\
\hline Porosity [\%] & 58.5 & \multicolumn{2}{|r}{}
\end{tabular}

\section{Contact angles of water}

The mean water-contact angles obtained from five measurements are presented graphically in Figure 3.

The analysis of the results presented in Table 4 indicated that the contact angle values depended on the type of the hydrophobic preparations. The results of the measurements of the contact angles revealed that the water-contact angle $\left(\theta_{w}\right)$ decreased with time in all cases. The smallest water-contact angle $\theta_{w}=40.15^{\circ}$ was obtained for the standard samples at time $t_{1}=0$, and the largest one $\theta_{w}=105.47^{\circ}$ was found at time $t_{1}=0$ for coating A2, which implies high hydrophobicity of the surface provided by this preparation. The largest decrease (by $35.27 \%$ ) in the value of the contact angle $\theta_{w}=14.16^{\circ}$ was observed within 40 minutes after application of water droplets onto the standard samples. In the lightweight-aggregate concrete hydrophobised with coating A2, the contact angle decreased slightly by $5 \%$. In the case of application of coating A1, the contact angle decreased by $13 \%$ after 40 minutes. 


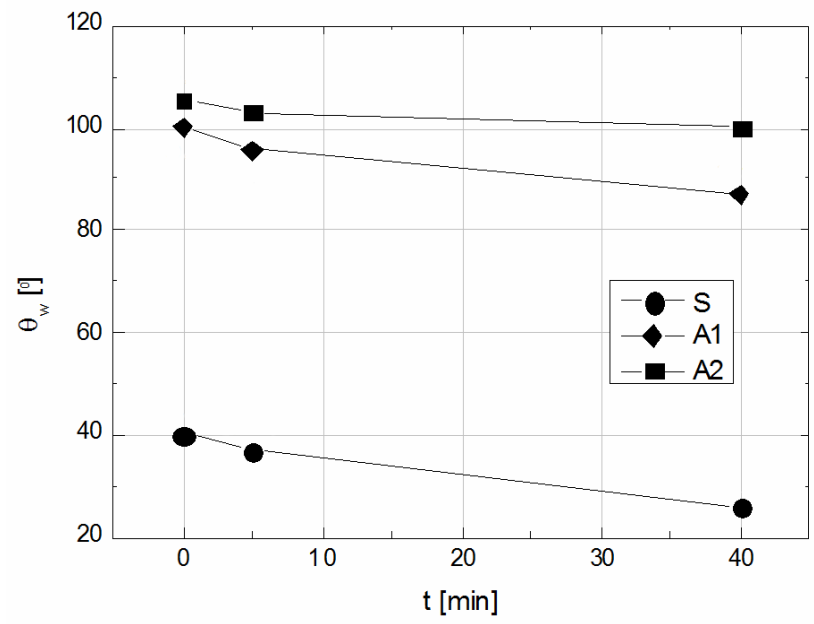

Fig. 3. Water-contact angles in lightweight-aggregate concrete modified with sewage sludge

\section{Microstructural analysis using Scanning Electron Microscopy}

SEM microscopic analyses were performed to verify the distribution and effectiveness of the hydrophobic coatings A1, A2 in the pores of the lightweight-concrete with sludge. The microstructure of the lightweight-concrete is shown in Figure 4.

a)

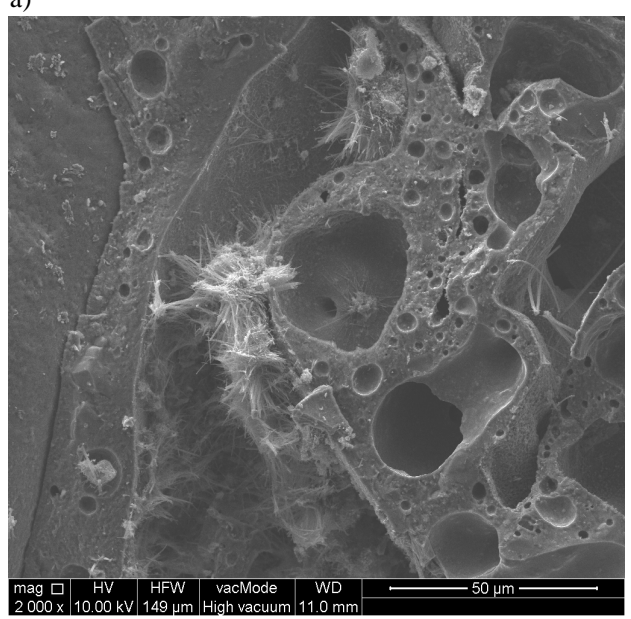

b)

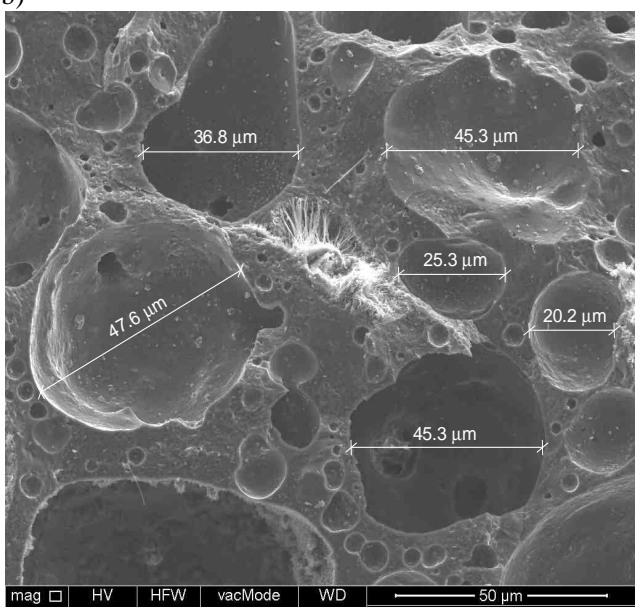

Fig. 4. Scanning microscope images of the structure: a) lightweight aggregate-concrete, b) lightweight aggregates with measurement of pore sizes

Hardened Portland cement mortar mainly consists of ca. $68 \%$ of calcium silicate hydrate, ie the so-called C-S-H phases, ca. $22 \%$ of calcium hydroxide and aluminate hydration products, as well as calcium aluminate ferrite. Microscopic observations at the 
interface of lightweight-aggregate concrete grains and cement mortar showed their good adhesion. There were no cracks or empty spaces at the contact site. Small amounts of needle-shaped ettringite crystals were present in the lightweight-aggregate concrete cement mortar (Fig. 4a). The microscopic observations showed that the diameter of larger pores of the lightweight aggregate modified with sewage sludge was $36 \mu \mathrm{m}$ on average (Fig. 4b).

The distribution of polysiloxane gel in the structure of lightweight-concrete is shown in Figure 5. The preparations applied to the structure of the standard samples formed a uniformly distributed coating with no visible flaws or cracks. The organic solvent agent A2 formed a silicon layer, covering the lightweight-aggregate concrete structure and sealing subsurface pores, which may cause a slight decrease in the mortar porosity. The porosity of the lightweight-aggregate concrete grains was unchanged. The water-soluble preparation A1 formed a discontinuous and very thin coating. It protected the lightweight concrete structure less efficiently as shown by the measurements of the contact angle, which decreased by $13^{\circ}$ within 40 minutes, whereas in the case of agent $\mathrm{A} 2$, the decline was only by $5^{\circ}$. Application of both formulations does not seal the pores excessively; hence, they should not disturb vapour permeability and water vapour diffusion.
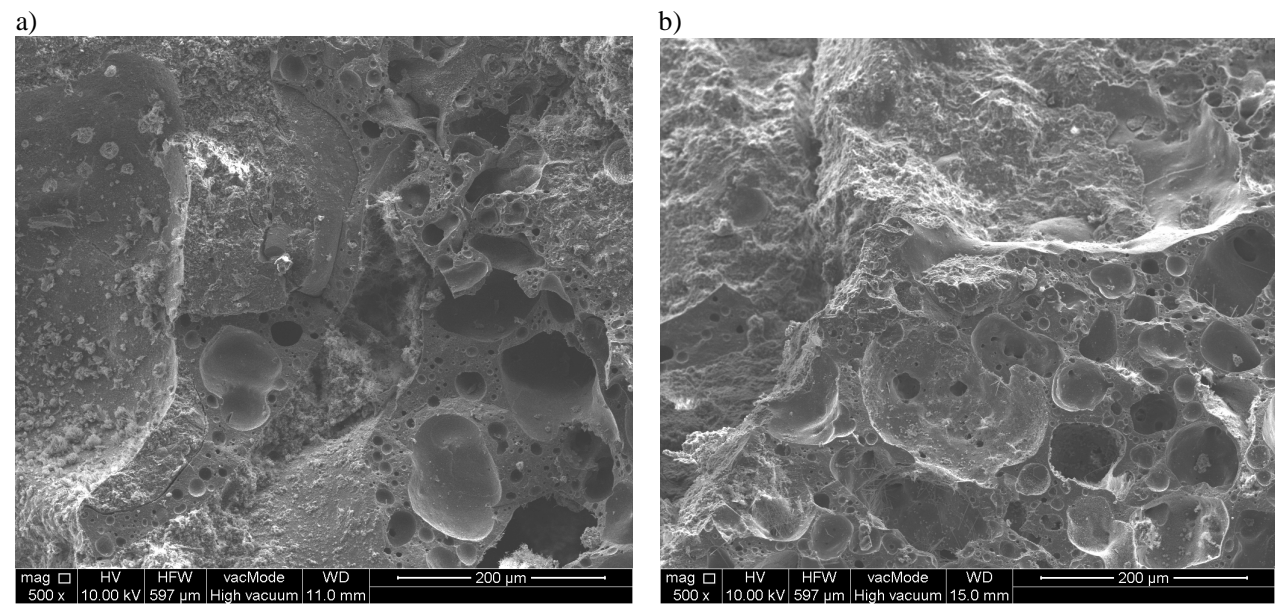

Fig. 5. Hydrophobized structure lightweight-concrete (500x): a) water-soluble preparation - A1, b) organic solvent-ased methylosilicone resin - A2

\section{Conclusions}

The presented examination has proved that sewage sludge can be applied as an additive for lightweight aggregate production, which can be successfully applied for the production of light concretes, as indicated by the results of the analysis of the physical and mechanical properties presented in this paper. Microscopic research of contact points between lightweight aggregates and cement mortar proved good adhesion. Due to increased absorption capacity and porosity produced by addition of sewage sludge to lightweight aggregate, there is a need for anti-moisture protection on the concrete surface.

Measurement of the contact angle is one of the methods for monitoring changes in the wettability of hydrophobised building materials. Application of different preparations 
results in differences in the wettability and adhesion properties of lightweight-aggregate concrete. It has been noted that hydrophobisation of the lightweight concrete surface yields different values of the contact angle. Its value increases significantly on a hydrophobised surface, in particular upon application of organic solvent-based methylosilicone resin. In the case of non-hydrophobised concrete, the contact angle values are 60-75-fold lower than those for an impregnated surface.

Depending on their chemical structure, organosilicon compounds applied on the subsurface of lightweight concrete reduce absorption capacity. This limits penetration of corrosive substances, ie soluble salts into the concrete structure, thereby improving its durability. On the other hand, hydrophobising agents applied do not seal the pores completely, which sustains vapour permeability of lightweight-aggregate concrete.

\section{Acknowledgements}

This work was financially supported partially by Polish Ministry of Science and Higher Education within the statutory research numbers S/14/2015, S/15/B/1/2015.

\section{References}

[1] Directive $86 / 278 /$ EEC. Council directive on the protection of the environment and in particular of the soil, when sewage sludge is used in agriculture. Official Journal of the European Communities. 1986;L(181):6-12. http://eur-lex.europa.eu/legal-content/EN/TXT/?uri=CELEX:31986L0278.

[2] Wos P, Dyka M, Korniluk M, Lagod G. Wpływ modernizacji urządzeń miejskiej oczyszczalni ścieków „Hajdów” na przebieg procesu oczyszczania ścieków oraz ilość powstających odpadów [Influence of "Hajdow" wastewater treatment plant modernization on wastewater purification process and amount of emerging waste]. Proc ECOpole. 2007;1(1-2):277-281.

[3] Werle S, Dudziak M. Gaseous fuels production from dried sewage sludge via air gasification. Waste Manage Res. 2014;32(7):601-607. DOI: 10.1177/0734242X14536460.

[4] Werle S, Wilk RK. A review of methods for the thermal utilization of sewage sludge: The Polish perspective. Renew Ener. 2010;35(9):1914-1919. DOI: 10.1016/j.renene.2010.01.019.

[5] Song U, Lee EJ. Environmental and economical assessment of sewage sludge compost application on soil and plants in a landfill. Resour Conser Recyc. 2010;54(12):1109-1116. DOI: 10.1016/j.resconrec.2010.03.005.

[6] Frac M, Oszust K, Lipiec J, Jezierska-Tys S, Oluchi Nwaichi E. Soil microbial functional and fungal diversity as influenced by municipal sewage sludge accumulation. Int J Environ Res Pub Health. 2014;11:8891-8908. DOI: 10.3390/ijerph110908891.

[7] Singh RP, Agrawal M. Potential benefits and risks of land application of sewage sludge. Waste Manage. 2008;28(2):347-358. DOI: 10.1016/j.wasman.2006.12.010.

[8] Gunning PJ, Hills CD, Carey PJ. Production of lightweight aggregate from industrial waste and carbon dioxide. Waste Manage. 2009;29(10):2722-2728. DOI: 10.1016/j.wasman.2009.05.021.

[9] Gonzáles-Corrochano B, Alonso-Azcárate J, Rodas M, Luque FJ, Barrenechea JF. Microstructure and mineralogy of lightweight aggregates produced from washing aggregate sludge, fly ash, and used motor oil. Cem Concr Composit. 2010;32(9):694-707. DOI: 10.1016/j.cemconcomp.2010.07.014.

[10] Suchorab Z, Barnat-Hunek D, Franus M. Analysis of heat-moisture properties of hydrophobised gravelite-concrete with sewage sludge. Proc ECOpole (in print).

[11] Lee TC, Lin KL, Su XW, Lin KK. Recycling CMP sludge as a resource in concrete. Constr Build Mater. 2012;30:243-251. DOI: 10.1016/j.conbuildmat.2011.11.019.

[12] Tay JH, Show KY. Resources recovery of sludge as a building and construction material - a future trend in sludge management. Water Sci Technol. 1997;36(11):259-266. DOI: 10.1016/S0273-1223(97)00692-6.

[13] Youm KS, Jeong YJ, Han ESH, Yun TS. Experimental investigation on annual changes in mechanical properties of structural concretes with various types of lightweight aggregates. Constr Build Mater. 2014;73:442-451. DOI: 10.1016/j.conbuildmat.2014.09.044. 
[14] Monteiro SN, Alexander J, Margem JI, Sánchez R, Vieira CMF. Incorporation of sludge waste from water treatment plant into red ceramic. Constr Build Mater. 2008;22(6)1281-1287. DOI: 10.1016/j.conbuildmat.2007.01.013.

[15] Aldred JM, Swaddiwudhipong S, Lee SL, Wee TH. The effect of initial moisture content on water transport in concrete containing a hydrophobic admixture. Mag Concr Res. 2001;53(2):127-134. DOI: 10.1680/macr.53.2.127.39509.

[16] Demirba R, Gül R. The effects of expanded perlite aggregate, silica fume and fly ash on the thermal conductivity of lightweight concrete. Cem Concr Res. 2003;33(5):723-727. DOI:10.1016/S00088846(02)01032-3.

[17] Kim HK, Jeon JH, Lee HK. Workability, and mechanical, acoustic and thermal properties of lightweight aggregate concrete with a high volume of entrained air. Constr Build Mater. 2012;29:193-200. DOI: 10.1016/j.conbuildmat.2011.08.067.

[18] Suchorab Z, Barnat-Hunek D, Sobczuk H. Influence of moisture on heat conductivity coefficient of aerated concrete. Ecol Chem Eng S. 2011;18(1):111-120. http://tchie.uni.opole.pl/freeECE/S_18_1/ Suchorab_18(S1).pdf.

[19] Suchorab Z, Widomski M, Lagod G, Sobczuk H. Capillary rise phenomenon in aerated concrete, monitoring and simulations. Proc ECOpole. 2010;4(2):285-290. http://tchie.uni.opole.pl/ecoproc10b/ SuchorabWidomski_PECO10_2.pdf.

[20] Lo TY, Cui HZ, Tang WC, Leung WM. The effect of aggregate absorption on pore area at the interfacial zone of lightweight concrete. Constr Build Mater. 2008;22(4):135-142. DOI: 10.1016/j.conbuildmat.2006.10.011.

[21] Tittarelli F. Oxygen diffusion through hydrophobic cement-based materials. Cem Concr Res. 2009;39(10):924-928. DOI: 10.1016/j.cemconres.2009.06.021.

[22] Suchorab Z, Barnat-Hunek D, Smarzewski P, Pavlík Z, Černý R. Free of volatile organic compounds protection against moisture in building materials. Ecol Chem Eng S. 2014;21(3):401-411. DOI: 10.2478/eces-2014-0029.

[23] Baltazar L, Santana J, Lopes B, Correia JR, Rodrigues MP. Superficial protection of concrete with epoxy resin impregnations: influence of the substrate roughness and moisture. Mater Struct. 2015;48:1931-1946. DOI: $10.1617 / \mathrm{s} 11527-014-0284-9$.

[24] Osterholtz FD, Pohl ER. Kinetics of the hydrolysis and condensation of organofunctional alkoxysilanes: a review. J Adhes Sci Technol. 1992;6(2):127-149. DOI: 10.1163/156856192X00106.

[25] Czarnecki L. Polymer concretes. Cem Wap Bet. 2010;15(2):63-85.

[26] Felekoğlu B. A method for improving the early strength of pumice concrete blocks by using alkyl alkoxy silane (AAS). Constr Build Mater. 2012;28(1):305-310. DOI: 10.1016/j.conbuildmat.2011.07.026.

[27] Zhu YG, Kou SC, Poon CS, Dai JG, Li QY. Influence of silane-based water repellent on the durability properties of recycled aggregate concrete. Cem Concr Composit. 2013;35(1)32-38. DOI: 10.1016/j.cemconcomp.2012.08.008.

[28] Xiong G, Luo B, Wu X, Li G, Chen L. Influence of silane coupling agent on quality of interfacial transition zone between concrete substrate and repair materials. Cem Concr Composit. 2006;28(1):97-101. DOI: 10.1016/j.cemconcomp.2005.09.004.

[29] Chmielewska B, Czarnecki L, Sustersic J, Zajc A. The influence of silane coupling agents on the polymer mortar. Cem Concr Composit. 2006;28(9):803-810. DOI: 10.1016/j.cemconcomp.2006.04.005.

[30] Klisinska-Kopacz A, Tislova R. Effect of hydrophobization treatment on the hydration of repair Roman cement mortars. Constr Build Mat. 2012;35:735-740. DOI: 10.1016/j.conbuildmat.2012.05.002.

[31] MacMullen J, Zhang Z, Rirsch E, Dhakal HN, Bennett N. Brick and mortar treatment by cream emulsion for improved water repellence and thermal insulation. Ener Build. 2011;43(7):1560-1565. DOI:10.1016/j.enbuild.2011.02.014.

[32] Matziaris K, Stefanidou M, Karagiannis G. Impregnation and superhydrophobicity of coated porous low-fired clay building materials. Progr Organic Coat. 2011;72(1-2):181-192. DOI: 10.1016/2011.03.012.

[33] Rudawska A. Selected issues on establishing adhesion bonds - homogeneous and hybrid. Lublin: Monographs Lublin University of Technology; 2013.

[34] PN-EN 828:2000 Adhesives. Determining wettability by means of measuring the contact angle and critical surface tension of solid. http://sklep.pkn.pl/pn-en-828-2000p.html.

[35] Lugscheider E, Bobzin K. The influence on surface free energy of PVD-coatings. Surf Coat Technol. 2001;142:755-760. DOI: 10.1016/S0257-8972(01)01315-9.

[36] Vedantam S, Panchagnula MV. Constitutive modeling of contact angle hysteresis. J Colloid Interf Sci. 2008;321(2):393-400. DOI: 10.1016/j.jcis.2008.01.056. 
[37] Courard L, Piotrowski T, Garbacz A. Near-to-surface properties affecting bond strength in concrete repair. Cem Concr Composit. 2014;46:73-80. DOI: 10.1016/j.cemconcomp.2013.11.005.

[38] Żenkiewicz M, Rytlewski P, Czupryńska P, Polański J, Karasiewicz T, Engelgard W. Contact angle and surface free energy of electron-beam irradiated polymer composites. Polimery. 2008;53(6):446-451.

[39] Shang J, Flury M, Harsh JB, Zollars RL. Comparison of different methods to measure contact angles of soil colloids. J Colloid Interf Sci. 2008;328(8):299-307. DOI:10.1016/j.jcis.2008.09.039.

[40] Klein NS, Bachmann J, Aguado A, Toralles-Carbonari B. Evaluation of the wettability of mortar component granular materials through contact angle measurements. Cem Concr Res. 2012;42(2):1611-1620. DOI: 10.1016/j.cemconres.2012.09.001.

[41] EN 206-1:2003/A2:2006P Concrete. Specification, performance, production and conformity. http://sklep.pkn.pl/pn-en-206-1-2003-a2-2006p.html.

[42] PN-B-06265:2004 Polish National Supplement: PN-EN 206-1:2003 Concrete. Specification, performance, production and conformity. http://sklep.pkn.pl/pn-en-206-2014-04e.html.

[43] EN 1936:2010 Natural stone test methods - Determination of real density and apparent density, and of total and open porosity. http://sklep.pkn.pl/pn-en-1936-2010p.html.

[44] PN-EN 1389:2005 Polish National Supplement: PN-EN 206-1:2003 Concrete. Specification, performance, production and conformity. http://sklep.pkn.pl/pn-en-1389-2005p.html.

[45] PN-EN 12390-7:2011P Testing hardened concrete. Density of hardened concrete. http://sklep.pkn.pl/pn-en-12390-7-2011p.html.

[46] PN-B-06250:1988 Ordinary concrete. http://sklep.pkn.pl/pn-b-06250-1988p.html.

[47] Rudawska A, Jacniacka E. Analysis of determining surface free energy uncertainty with the Owens-Wendt method. Intern J Adhes Adhesives. 2009;29:451-457. DOI: 10.1016/j.ijadhadh.2008.09.008.

\title{
OCENA KĄTA ZWILŻANIA HYDROFOBIZOWANEGO KERAMZYTOBETONU Z OSADEM ŚCIEKOWYM
}

${ }^{1,2}$ Wydział Budownictwa i Architektury, Politechniki Lubelska

${ }^{3}$ Wydział Inżynierii Środowiska, Politechnika Lubelska

\begin{abstract}
Abstrakt: Celem badań przedstawionych w pracy była ocena efektu zastosowania preparatów hydrofobowych opartych o substancje krzemoorganiczne do zabezpieczania lekkich bloczków keramzytowych z dodatkiem osadów ściekowych przed wilgocią. W artykule omówiono zagadnienia związane ze zwilżalnością warstwy wierzchniej hydrofobizowanego keramzytobetonu modyfikowanego osadem ściekowym. Część doświadczalna pracy dotyczy cech fizycznych i mechanicznych keramzytobetonu oraz wpływu dwóch preparatów hydrofobowych na kąt zwilżania materiału. Wyznaczono kąt zwilżania betonu lekkiego $\left(\theta_{w}\right) \mathrm{w}$ funkcji czasu przy użyciu jednej cieczy pomiarowej. Przedstawiono powłoki hydrofobowe w strukturze betonu lekkiego z osadem przy użyciu mikroskopii elektronowej. Na podstawie badań określono skuteczność hydrofobizacji porowatych betonów lekkich. Dla użytych substancji hydrofobizujących kąty zwilżania zmniejszały się z upływem czasu, a zmiana zależała od zastosowanych preparatów. Wyniki przeprowadzonych badań potwierdziły możliwość poprawy parametrów betonów lekkich wraz z odpowiednim zabezpieczeniem powierzchniowym przed wilgocią z zewnątrz.
\end{abstract}

Słowa kluczowe: osady ściekowe, keramzytobeton, hydrofobizacja, kąt zwilżania, mikrostruktura 